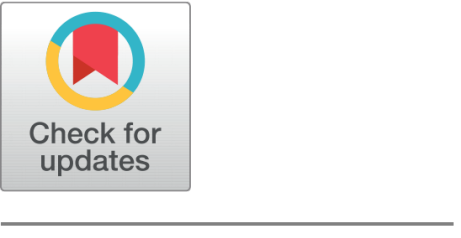

OPEN ACCESS

Received: 08.02.2021

Accepted: 11.06 .2021

Published: 02.11 .2021

Citation: Irfan S, Rana SSA, Sani IA, Haun L, Weixue M, Jabeen $R$, Ahmed N (2021) Characterization of the Complete Chloroplast Genome Sequence of Juniperus polycarpos K. Koch (Cupressaceae), from Ziarat, Pakistan. Indian Journal of Science and Technology 14(36): 2806-2814. https://doi.org/

10.17485/IJST/v14i36.151

* Corresponding author.

nazeer.ahmed@buitms.edu.pk

Funding: None

Competing Interests: None

Copyright: (c) 2021 Irfan et al. This is an open access article distributed under the terms of the Creative Commons Attribution License, which permits unrestricted use, distribution, and reproduction in any medium, provided the original author and source are credited.

Published By Indian Society for Education and Environment (iSee)

ISSN

Print: 0974-6846

Electronic: 0974-5645

\section{Characterization of the Complete Chloroplast Genome Sequence of Juniperus polycarpos K. Koch (Cupressaceae), from Ziarat, Pakistan}

\author{
Shazia Irfan $\circledast^{1}$, Shajahan Shabbir Ahmed Rana ${ }^{2}$, Imran Ali Sani ${ }^{2}$, \\ Liu Haun ${ }^{2}{ }^{2}$, Mu Weixue $\mathbb{D}^{3}{ }^{3}$, Ruksana Jabeen ${ }^{1}{ }^{1}$, Nazeer Ahmed ${ }^{2 *}$ \\ 1 Department of Botany, Faculty of life Sciences, Sardar Bahadur Khan Women's University, \\ Quetta, Pakistan \\ 2 Department of Biotechnology, (Balochistan University of Information Technology, \\ Engineering and Management Sciences), Quetta, Pakistan \\ 3 China National Gene Bank, Shenzhen, China
}

\section{Abstract}

Objectives: To broaden the genetic information base of Juniperus and resolve phylogeny of Juniperus polycarpos through sequencing and characterization of its chloroplast genome. Methods: The chloroplast (cp) genome of J. polycarpos was sequenced and assembled using the Next-Generation Sequencing pairedend reads platform of BGISEQ-500 and annotated using CpGAVAS. The phylogenetic analysis was performed in MEGA7. Findings: Here, we report the complete cp genome sequence of $J$. polycarpos. The cp genome size is 127,825 bp with a typical circular structure and lack canonical inverted repeats having a total of 119 genes comprised of 82 protein-coding genes, 33 tRNA genes and four rRNA genes. The cp genome encodes 105 single copy genes and five duplicated genes ( $n d h K, \operatorname{ccS} A, r p s 12, \operatorname{trnE}-T T C$ and trnQ-TTG), and one tetraplicated gene(trnM-CAT). In these genes, 9 genes (rp/2, ycf2, trnA-TGC, trnE$T T C, r p o C, r p o B, n d h B, n d h A$ and $a t p F$ ) harboring a single intron, three genes ( $a c c D, r r n 23 s$ and $y c f 3$ ) having two introns and one gene ( $y c f 1)$ harboring three introns. The overall GC content of J. polycarpos chloroplast DNA was 35\%. Phylogenetic analysis among 14 species of order Coniferales based on $\mathrm{cp}$ genomes indicated a close relationship between J. polycarpos, J. cedrus and J. communis. Novelty and application: This is the first report on the cp genome of J. polycarpos. The current study is expected to add to the already available genomic resources needed for more comprehensive population genetics studies and resolving phylogenetic relationships of order Coniferales. Besides, it will provide baseline data for future research on Juniperus of Pakistan in particular.

Keywords: BGISeq-500; Cloroplast Genome; Persian Juniper; Phylogeny 


\section{Introduction}

The genus Juniperus (Cupressaceae), commonly known as "cedar", is among the most diverse genera of conifers: lacking consensus, however, on number of species. Farjon ${ }^{(1)}$, for example, reported 52 species of Juniperus while Adams ${ }^{(2)}$ documented 67 species. In Pakistan, five species of Juniperus are reported. The Juniperus L. are divided into two sections (Juniperus and Sabina) and three subsections; (Juniperus, Oxycedrus and Caryocedrus), though some studies treat Caryocedrus as a complete section rather than subsection ${ }^{(3,4)}$. Juniperus L. genus are geographically widely distributed occurring across the Northern hemisphere, Arctic, Central American mountains, East Africa, Central Asia, and South Asia ${ }^{(2,5,6)}$.

The Juniper forest (Juniperus polycarpos) of Ziarat area in the province of Balochistan, Pakistan, are stretched on an area of $110000 \mathrm{ha}$ and is said to be the second largest of its kind in the world. The trees of juniper here are believed to be among the oldest living trees in the world and are, therefore, referred to as "living fossils" ${ }^{(7)}$ making the species of immense importance for climate change and ecological studies.

The forest lies in the dry temperate woodland region where J. polycarpos is disbursed between $20^{\circ} 9^{\prime} \mathrm{N}$ and $30^{\circ} 37^{\prime} \mathrm{N}$ and between $67^{\circ} 1^{\prime} \mathrm{E}$ and $68^{\circ} 3^{\prime} \mathrm{E}$, with elevation ranging from $1200 \mathrm{~m}$ to 3000 meters above sea level ${ }^{(8)}$. Besides supporting diverse plant species, the juniper ecosystem provides habitat for endangered wildlife species; including Black bear and the Sulaiman Markhor. The Juniper forest of Ziarat, in view of its importance for biodiversity, climate change and ecology, was declared the Biosphere Reserve in 2013 by UNESCO. Similarly, owing to old growing trees and large area, the ecosystem (as part of the global forest vegetation) has attained enormous importance as carbon stock ${ }^{(2)}$

J. polycarpos K. Koch is a part of the J. excelsa complex, one of the most complicated taxonomic groups of Juniperus ${ }^{(9)}$. This complex consists of four morphologically cryptic taxa, and when recognized at the specific level are: J. excelsa M. Bieb., J. seravschanica Kom, J. polycarpos K. Koch, and J. turcomanica B. Fedtsch ${ }^{(10)}$. The phylogenies indicated that the J. excelsa complex is composed of three distinct clades at the species level: J. excelsa, J. polycarpos and J. seravschanica and two varieties of J. polycarpos: J. polycarpos var. polycarpos and J. polycarpos var. turcomanica. ${ }^{(11)}$. In many studies, J. excelsa and J. polycarpos are grouped as a unit ${ }^{(12,13)}$. Differences, however, exist between the two. In a study conducted in Iran, J. excelsa is termed unisexual (dioecious) while J. polycarpos as ambisexual (monoecious) ${ }^{(14)}$. Contrary to that a recent publication suggests J. excelsa as both monoecious and dioecious while J. polycarpos as dioecious only ${ }^{(15,16)}$. The Juniper of Ziarat in many studies is still listed under the name of Juniperus excels subsp. polycarpos, although RAPD and essential oil analysis indicated that the taxon should be treated as J. polycarpos ${ }^{(17)}$.

The current work is an attempt to broaden the genetic information base of the Juniperus. Advancement in sequencing technologies has opened avenues for revealing complete chloroplast genomic information in abundance of species. In this study, we characterized complete cp genome of J. polycarpos based on Next-Generation Sequencing approach using BGISEQ500 followed by a de novo and reference guided assembly. We analyzed the genome features of $J$. polycarpos and compared them with cp genomes from other Gymnosperm species. We used cp genome and 14 shared cp genes to perform phylogenomic analysis to study the phylogeny of order Coniferales and resolve the phylogenetic position of J. polycarpos.

\section{Materials and Methods}

\subsection{Plant material}

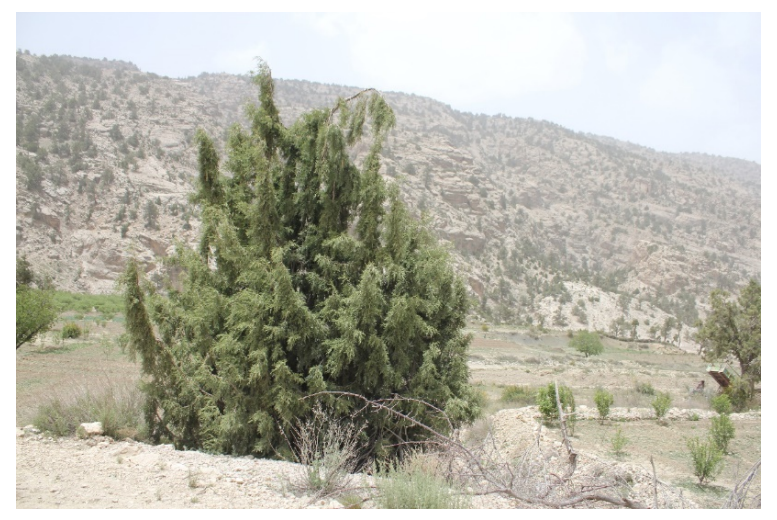

Fig 1. Juniperus polycarpos collected from Sasmamanna. 
Young leaves of $J$. polycarpos were collected on silica gel from Ziarat, Balochistan, Pakistan at $30.37537^{\circ} \mathrm{N}, 067.70660^{\circ} \mathrm{E}$ and $2575 \mathrm{~m}$ (Figure 1). The voucher specimens were deposited at Balochistan University of Information Technology, Engineering, and Management Sciences (HBUITEMS) Herbarium.

\subsection{Chloroplast genome sequencing, assembly and annotation}

Total genomic DNA from the silica-dried leaves of J. polycarpos was extracted using DNeasy Plant Mini Kit (QIAGEN Inc., Valencia, CA, USA). The whole genome of J. polycarpos was sequenced and assembled using the Next-Generation Sequencing paired-end reads platform of BGISEQ-500 (BGI, Shenzhen). We respectively used SOAPfilter_v2.2 and seed-extension-based de novo assembler NOVOPlasty v2.6.1 ${ }^{(18)}$ to filter low quality raw reads and carrying out de novo assemblies of whole genome. To conduct the assemblies, complete $\mathrm{rbcL}$ gene sequence of $J$. excelsa, accession number HM024303, downloaded from National Center for Biotechnology Information (NCBI, https://www.ncbi.nlm. nih.gov/) was used as the seed. The J. cedrus, was used, as a reference for further assembly with the help of 'mitochondrial baiting and iterative mapping' approach assembler MITObim v1.8 ${ }^{(19)}$ to recover complete plastid genomes of $J$. polycarpos. To retrieve the missing sequence, imputation technique was utilized. To carry out imputation, eight closely related complete genome sequences of Juniperus sp. (Table 1) to J. polycarpos were downloaded from NCBI via BLASTn. Pairwise and multiple alignments were carried out using ClustalW (BioEdit). After the sequences were aligned, consensus sequence was generated in BioEdit $7^{(20)}$. The consensus sequence was considered as a reference sequence and was aligned with the sample sequence via ClustalW. A huge gap was observed in sample sequence after alignment, the sequence was copied from reference and was attached in sample sequence where huge gap was generated. Eventually, the complete chloroplast genome was annotated using CpGAVAS (http://www.herbalgenomics. org) and the primary annotated results were corrected using Dual Organellar GenoMe Annotator - DOGMA - and Basic Local Alignment Search Tool - BLAST. tRNAscanSE was used to identify the tRNAs.

Table 1. Complete Chloroplast genomes of Coniferales downloaded from GenBank.

\begin{tabular}{lll}
\hline$\#$ & Chloroplast Genome & Accession number \\
\hline 1 & Juniperus cedrus & KT378453.1 \\
2 & Juniperus scopulorum & KF866299.1 \\
3 & Juniperus microsperma & NC_037430.1 \\
4 & Juniperus virginiana & KF866300.1 \\
5 & Juniperus sabina strain JSTL & NC_039644.1 \\
6 & Juniperus formosana & KX832625.1 \\
7 & Juniperus bermudiana & KF866297.1 \\
8 & Juniperus monosperma & KF866298.1 \\
9 & Juniperus communis & MH121052.1 \\
10 & Callitropsis vietnamensis & KX832629.1 \\
11 & Hesperocyparis benthamii & NC_039565.1 \\
12 & Cupressus jiangeensis & MG596347.1 \\
13 & Thuja standishii & KX832627.1 \\
14 & Taxus fauna & NC_038099.1 \\
\hline
\end{tabular}

\subsection{Phylogenetic analysis}

We downloaded $14 \mathrm{cp}$ genomes of closely related species of order Coniferales from GenBank to study the phylogenetic relationships among Juniperus sp. (Table 1). Callitropsis vietnamensis, Cupressus jiangeensis, Thuja standishii, Hesperocyparis benthami, and Taxus fauna were used as out-group. Initially, multiple sequence alignments of complete cp genomes, based on the conserved structure and gene order, were carried out by using BioEdit ${ }^{(20)}$ with default parameters. Neighbor-Joining tree were constructed $^{(21)}$ in MEGA $7^{(22)}$ with 1000 bootstrap replicates and Kimura 2-parameter ${ }^{(23)}$. 


\section{Results}

\subsection{Genome assembly and genome features of $J$ polycarpos}

The complete genome of $J$. polycarpos was sequenced using Next-Generation Sequencing approach (BGISEQ-500) utilizing Denovo and reference-based assembly. The sequencing produced raw data of about $65 \mathrm{~Gb}$ for the whole genome with an average read length of $100 \mathrm{bp}$. Using J. cedrus rbcL region as seed, we extracted and assembled Chloroplast genome of $J$. polycarpos from the whole genome by means of the 'mitochondrial baiting and iterative mapping' approach assembler MITObim v1.8 ${ }^{(19)}$. We recovered the missing junk of approximately $441 \mathrm{bp}$ by Imputation technique after comparing cp genome of J. polycarpos with cp genome of J. cedrus and annotating by web-based program CPGAVAS ${ }^{(24)}$. DOGMA was used to check and curate the annotations for missing annotations.

The cp genome of J. polycarpos was $127,825 \mathrm{bp}$ in length. The assembled cp genome was a typical circular molecule that lack canonical inverted repeats which separate the small and large single copy regions (Figure 2). The chloroplast genome map of $J$. polycarpos is given in Figure 2. The overall GC content of the cp genome was 35\%.

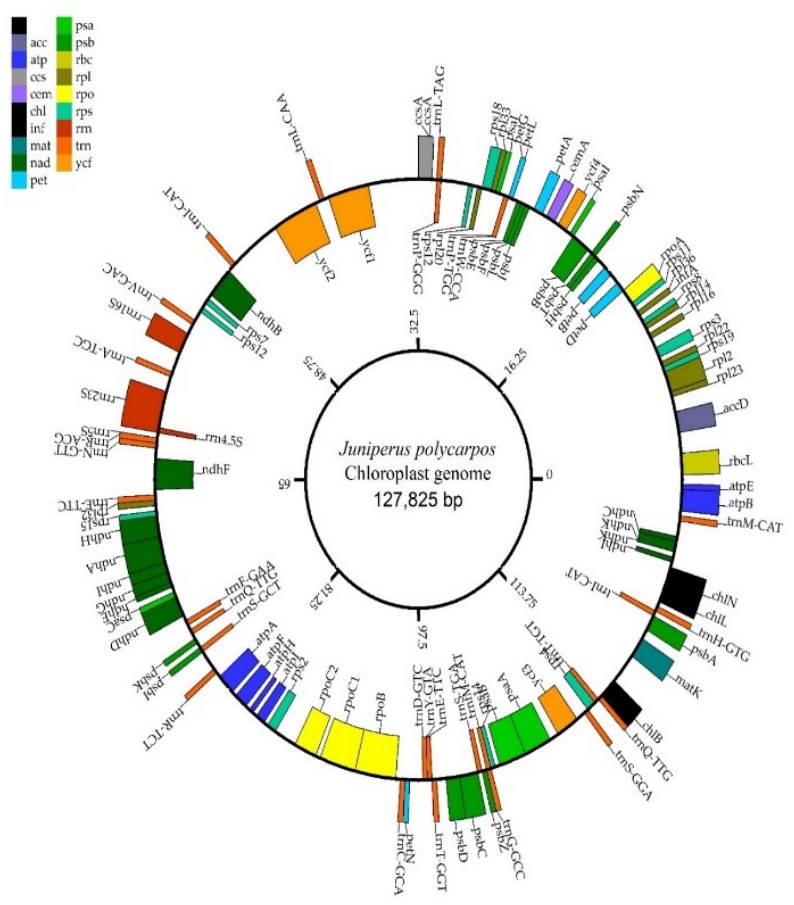

Fig 2. Complete chloroplast genome map of J. polycarpos. Genes inside the circle are transcribed in clockwise direction, while those outsides are transcribed in counterclockwise direction

\subsection{Cp Genome Annotation}

The cp genome of $J$. polycarpos contained 119 genes divided into the following three categories: 82 protein-coding genes, 4 ribosomal RNA genes and 33 transfer RNA genes (Table 2). 
Table 2. Juniperus polycarpos gene list edited by CPGAVAS

\begin{tabular}{|c|c|c|}
\hline Gene Kinds & Gene set & Genes \\
\hline \multirow{7}{*}{ Photosynthetic Genes } & Photosystem I Subunits & PsaI, PsaJ, PsaC, PsaB,PsaA \\
\hline & Photosystem II Subunits & $\begin{array}{l}p s b Z, p s b T, p s b N, p s b L, p s b K, p s b J, p s b I, p s b H, p s b F, p s b E, p s b D \\
p s b C, p s b B, p s b A\end{array}$ \\
\hline & Cytochrome Subunits & pet $N$, pet $L, \operatorname{pet} G, \operatorname{pet} D, \operatorname{pet} B, \operatorname{pet} A$ \\
\hline & ATP synthase Subunits & atpI, atpH, atpF, atpE, atpB, atpA \\
\hline & RuBisCO Large Subunit & $R b c L$ \\
\hline & NADH dehydrogenase Subunits & $\begin{array}{l}n d h K, n d h J, n d h I, n d h H, n d h G, n d h F, n d h E, n d h D, n d h C, n d h B^{*}, \\
n d h A^{*}\end{array}$ \\
\hline & Biosynthesis of Chlorophyll & ChlN, ChlB ChlL \\
\hline \multirow{6}{*}{ Miscellaneous Genes } & Maturase & MatK \\
\hline & Cytochrome synthesis c-Type gene & $\operatorname{ccs} A(\times 2)$ \\
\hline & Acetyl-CoA-carboxylase Subunit & $\operatorname{acc} D^{\star *}$ \\
\hline & Protein of Envelope membrane & CemA \\
\hline & Conserved open reading frames & $y c f 4, y c f 3^{* *}, y c f 1^{* * *}$ \\
\hline & $\begin{array}{l}\text { Conserved open reading frames of } \\
\text { unknown function }\end{array}$ & $y c f 2^{*}$ \\
\hline \multirow[t]{6}{*}{$\begin{array}{l}\text { Genes for Auto } \\
\text { replication }\end{array}$} & Transfer RNA genes & 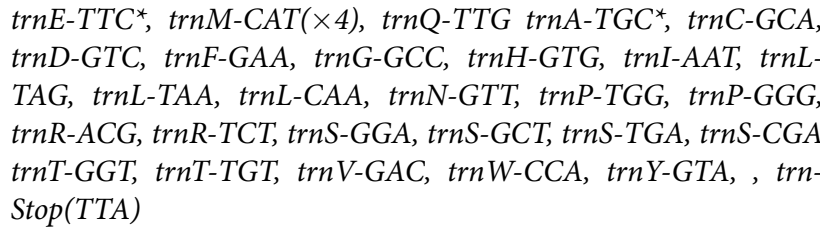 \\
\hline & RNA genes for Ribosomes & $r r n 23^{* *}, r r n 16, r r n 5, r r n 4.5$ \\
\hline & LSU (Ribosome Large Subunit) & rpl36, rpl33, rpl32, \\
\hline & SSU (Ribosome Small Subunit) & $\begin{array}{l}\text { rps12, rps19, rps18, rps15, rps14, rps11, rps8, rps7, rps4, rps3, rps2, } \\
\text { rpl23, rpl22, rpl20, rpl16, rpl14, rpl2* }\end{array}$ \\
\hline & RNA polymerase & 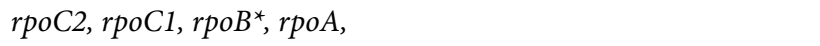 \\
\hline & Initiation factor for Translation & $\operatorname{InfA}$ \\
\hline
\end{tabular}

Note: ${ }^{*}$ one intron containing genes; ${ }^{* *}$ Two intron containing genes; ${ }^{* *}$ Three intron containing genes. Boldface-type genes have two copies of the gene.

\subsubsection{Protein -coding genes}

Protein coding genes include 47 Genes for photosynthesis ( $p s a, p s b$, pet, atp, $r b c L$, ndh and chl), one gene of unknown function $(y c f 2)$, eight other genes with different functions ( $y c f 1, y c f 3, y c f 4$, matk, $c c s A, c e m A$ and $a c c D)$ and 26 self-replicating genes (Table 2). Among these genes, $r p l 2, y c f 2$, trnA-TGC, trnE-TTC, $r p o C, r p o B, n d h B$, $n d h A$ and atpF harbor a single intron, accD, rrn23s and ycf3 two introns and $y c f 1$ harbor three introns.

\subsubsection{Genes of unknown function.}

$y c f 2$ is a split gene with a single intron and unknown function.

\subsubsection{Other genes.}

Other genes included; maturase (matK), an envelope membrane protein (cemA), a subunit of acetyl-CoA carboxylase (accD), a c-type cytochrome synthesis gene(ccsA), Component of TIC complex (ycf1) and Subunits of photosystem I( $y c f 3$ and $y c f 4)$ [25].

\subsubsection{Self- Replication genes.}

The self-replicating genes included 9 rpl gene, 12 rps gene, 4 rpo gene and one infA gene (Table 2).

\subsubsection{Ribosomal RNA genes}

The four ribosomal RNA genes are $r r n 4.5, r r n 5, r r n 16, r r n 23$. The $r r n 23$ is a split gene harboring two introns ranging in size from $22 \mathrm{bp}$ (for $r$ rn23S) to $766 \mathrm{bp}$ (for $n d h A$ ). 


\subsubsection{Transfer RNA gene}

Thirty-three (33) transfer RNA were identified by CPGAVAS and validated by DOGMA and tRNAscan-SE (Table 2). tRNAscanSE identifies $99-100 \%$ of transfer RNA genes in DNA sequence whilst giving much less than one false superb per 15 gigabases. The Av. tRNA size is $89 \mathrm{bp}$ and it anticipated 29 tRNAs ensuing 28 tRNAs.

\subsubsection{Split Genes}

There are 13 split genes were identified in Chloroplast genome of J. polycarpos, in which 9 genes ( $r p l 2, y c f 2$, trnA-TGC, trnE$T T C, r p o C, r p o B, n d h B, n d h A$ and atpF) having single intron, three genes ( $a c c D, r r n 23 s$ and $y c f 3)$ having two introns and one gene ( $y c f 1)$ harboring three introns.

DOGMA validated all genes annotated by CPGAVAS and tRNAscan besides detecting three more genes viz., a conserved open reading frame gene of unknown function $y c f 68$ having three copies and two open reading frame genes orf 42 and orf 188 .

\subsection{Comparative Analyses of the Chloroplast Genome with Other Coniferales}

When compared to different Juniperus species the chloroplast genome has more or less similar genes except that there are five duplicated genes ( $n d h K, \operatorname{cs} A, r p s 12$, trnE-TTC and trnQ-TTG), and one tetraplicated gene(trnM-CAT) (Table 3 ) and 13 split genes (Table 3).

Table 3. Comparison of Chloroplast Genome of Cupressaceae.

\begin{tabular}{|c|c|c|c|c|c|c|c|c|}
\hline & $\begin{array}{l}\text { Juniperus } \\
\text { polycarpos }\end{array}$ & $\begin{array}{l}\text { Juniperus } \\
\text { tibetica }\end{array}$ & $\begin{array}{l}\text { Juniperus } \\
\text { Squamata }\end{array}$ & $\begin{array}{l}\text { Juniperus } \\
\text { recurve }\end{array}$ & $\begin{array}{l}\text { Juniperus } \\
\text { microsperma }\end{array}$ & $\begin{array}{l}\text { Juniperus } \\
\text { cedrus }\end{array}$ & $\begin{array}{l}\text { Cupressus } \\
\text { jiangeensis }\end{array}$ & $\begin{array}{l}\text { Cupressus } \\
\text { gigantean }\end{array}$ \\
\hline $\begin{array}{l}\text { Genome } \\
\text { Size(bp) }\end{array}$ & 127,825 & 127,662 & 127,792 & 127,602 & 127,409 & 127,126 & 128,286 & 128,244 \\
\hline Total Genes & 119 & 123 & 118 & 119 & 119 & 119 & 119 & 119 \\
\hline $\begin{array}{l}\text { Single copy } \\
\text { genes }\end{array}$ & 105 & 119 & 117 & 119 & 115 & 115 & 115 & 115 \\
\hline $\begin{array}{l}\text { Duplicated } \\
\text { genes }\end{array}$ & 5 & 2 & 1 & & 2 & 2 & 2 & 2 \\
\hline $\begin{array}{l}\text { Tetraplicated } \\
\text { genes }\end{array}$ & 1 & - & - & - & - & - & - & - \\
\hline $\begin{array}{l}\text { Protein- } \\
\text { coding } \\
\text { genes }\end{array}$ & 82 & 82 & 82 & 82 & 82 & 82 & 82 & 82 \\
\hline $\begin{array}{l}\text { Ribosomal } \\
\text { RNA genes }\end{array}$ & 4 & 4 & 4 & 4 & 4 & 4 & 4 & 4 \\
\hline $\begin{array}{l}\text { transfer } \\
\text { RNA genes }\end{array}$ & 33 & 33 & 32 & 33 & 33 & 33 & 31 & 31 \\
\hline $\begin{array}{l}\text { Single intron } \\
\text { genes }\end{array}$ & 9 & & & 8 & 8 & 8 & 8 & 8 \\
\hline $\begin{array}{l}\text { Double } \\
\text { introns } \\
\text { genes }\end{array}$ & 3 & & & 2 & 2 & 2 & 2 & 2 \\
\hline GC Content & $35 \%$ & $35.04 \%$ & 35.1 & $35.00 \%$ & $35 \%$ & $35 \%$ & $34.70 \%$ & $34.68 \%$ \\
\hline
\end{tabular}

\subsection{Phylogenetic analysis}

In the present study, 14 complete chloroplast genomes of six genera of order Coniferales were utilized to depict the phylogenetic relationships. The history of evolution was inferred using the Neighbor-Joining tree. The bootstrap consensus tree formed from 1000 replicates by using the Kimura 2-parameter method. The results showed that all Juniperus species involved were clustered into two supported monophyletic groups that belong to the Juniperus sect. Juniper and Juniperus sect. Sabina, respectively. Within the former J. polycarpos is more closely related to J. cedrus and J. communis (Figure 3). 


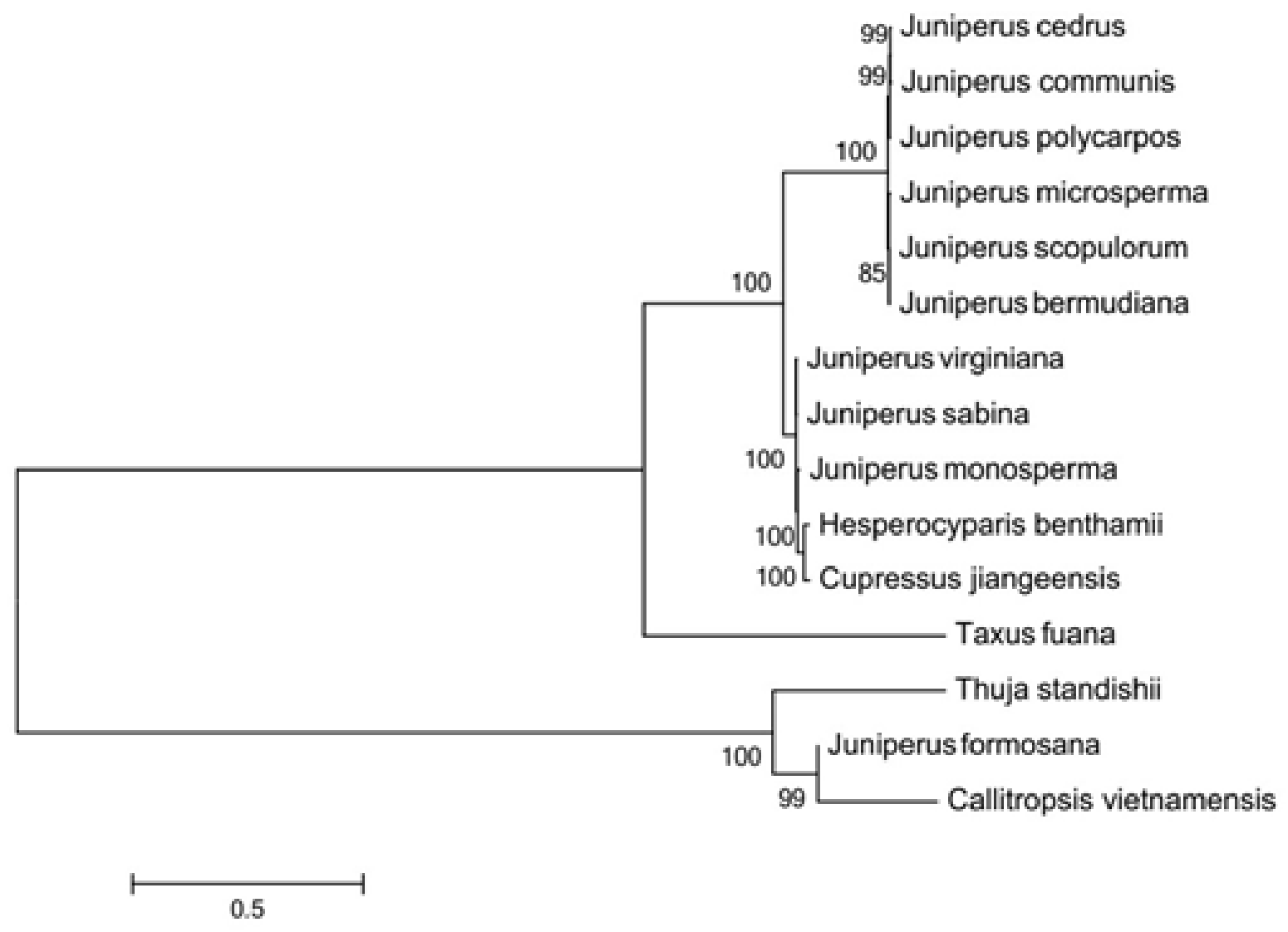

Fig 3. Neighbor Joining Tree among different Juniperus species and others Coniferales. Behind the nodes are shown the supporting values based on 1000 replicates.

\section{Discussion}

Gymnosperm chloroplast (cp) genomes, especially in coniferous species, have distinctive characteristics compared to those of angiosperms, including paternal inheritance ${ }^{(25-27)}$, relatively high levels of intra-specific variation ${ }^{(28,29)}$, and a different pattern of RNA editing ${ }^{(30)}$.

The complete cp genome of Juniperus polycarpos was assembled in the present work, using BGISEQ-500 (BGI, Shenzhen) paired-end reads derived from the whole genome. Several other studies have adopted similar strategy of obtaining the $\mathrm{cp}$ genome without prior isolation of the cpDNA ${ }^{(31-34)}$.

The size of the complete cp genome of J. polycarpos (127,825bp) was consistent with cp genomes from the other sequenced Juniperus species (i.e., ranging from 127,126 bp in J. cedrus to 127,792 bp in J. squamata (Table 3). The absence of inverted repeat (IR) sequence in conifers largely accounts for relatively small cp genome size, as observed for $J$. polycarpos in the present report and for other published works on cp genomes of Cupressaceae species ${ }^{(35-39)}$. Conifers like Douglas-fir and radiata pine also lack the large (20-25 kb) inverted repeat that characterizes most land plants ${ }^{(40)}$. Similarly, a single group of land plants consisting of several allied tribes in the subfamily Papilonoideae of the legume family (Fabaceae) lack major inverted repeat of roughly $10-76 \mathrm{~kb}$ that contains the rRNA genes and adjacent DNA which results in extensive genome sequence rearrangements ${ }^{(40,41)}$. The angiosperm cp genomes, on the other hand, range in size from 130 to $160 \mathrm{~kb}$, and contain two identical inverted repeats (IRs) splitting the genomes into Large (LSC) and small single-copy (SSC) regions ${ }^{(31)}$.

The overall GC content of the cp genome, which was 35\% in our work, corresponded with the GC contents calculated for other Juniper species (Table 3). The cp genome of J. polycarpos has typical Coniferales circular structure (Figure 2) with similar genes resembling other Juniperus species (Table 3 ).

Many phylogenetic studies in land plants have used genome sequences of chloroplast to analyze relatedness and identify the species ${ }^{(42-44)}$. Still in other similar studies some Coding Sequences (CDSs) e.g., matK, rbcL, rpoB and intergenic regions 
were used as barcode markers. However, low variability of plant barcode markers ${ }^{(45,46)}$, particularly for closely related species, necessitates genome-based analysis. The present report is a step forward in this direction. The availability and comparison of cp genomes will facilitate designing better barcode markers discriminating juniperus species.

Chloroplast genome based phylogenetic analyses in the current report provided strong support for the monophyly of $J$. polycarpos in the Coniferales; endorsing previous studies on the phylogeny of the Coniferales ${ }^{(47)}$. Our findings have further elucidated the phylogenetic relationships among Coniferales species. However, availability of additional complete chloroplast genome sequences will add to resolution of the comprehensive phylogenies of this order.

\section{Conclusion}

Our study maidenly reported the complete chloroplast genome of J. polycarpos. The cp genome organization and gene content were found similar to that of congeneric species. The comparative analysis of the genome structure of six Coniferales plants showed several variation hotspots, which could be used to develop more specific DNA barcodes for the authentication of Coniferales species. These highly variable regions also presented a resource for phylogenetic studies in the family Cupressaceae. We depicted the phylogenetic relationships of some species of order Coniferales and confirmed the phylogenetic relationship between J. cedrus and J. communis .

\section{References}

1) Farjon A. World checklist and bibliography of conifers: Royal Botanic Gardens. 2001. Available from: https://agris.fao.org/agris-search/search.do? recordID=US201300067359.

2) Adams RP, Schwarzbach AE. DNA barcoding a juniper: the case of the south Texas Duval county juniper and serrate junipers of North America. Phytologia. 2011;93(1):146-154.

3) Adams RP, Demeke T. Systematic relationships in Juniperus based on random amplified polymorphic DNAs (RAPDs). TAXON. 1993;42(3):553-571. Available from: https://doi.org/10.2307/1222534.

4) Mao K, Hao G, Liu J, Adams RP, Milne RI. Diversification and biogeography of Juniperus (Cupressaceae): variable diversification rates and multiple intercontinental dispersals. New Phytologist. 2010;188(1):254-272. Available from: https://dx.doi.org/10.1111/j.1469-8137.2010.03351.x.

5) Farjon A. Monograph of Cupressaceae and Sciadopitys: Royal Botanic Gardens. 2005. Available from: https://press.uchicago.edu/ucp/books/book/ distributed/M/bo9856365.html.

6) Shaheen H, Awan SN, Aziz S. Distribution Pattern, Conservation Status, and Associated Flora of the Genus Juniperus in Subalpine Pastures of the Kashmir Himalayas. Mountain Research and Development. 2017;37(4):487-487. Available from: https://dx.doi.org/10.1659/mrd-journal-d-16-00119.1.

7) Sheikh M. Afforestration in Juniper forests of Ziarat, Balochistan. Pak J For. 1985;p. 46.

8) Rafi M. Vegetation types of Baluchistan province. Lahore Pakistan. Pak Govt Printing Press Punjab. 1965.

9) Farjon A. The Taxonomy of multiseed Junipers (Juniperus sect.Sabina) in southwest Asia and East Africa (Taxonomic notes on Cupressaceae I). Edinburgh Journal of Botany. 1992;49(3):251-283. Available from: https://dx.doi.org/10.1017/s0960428600000524.

10) Güvendiren AD. Molecular phylogenetic analyses of juniperus l. Species in turkey and their relations with other junipers based on cpdna. Middle East Technical University. 2015. Available from: http://etd.lib.metu.edu.tr/upload/12618695/index.pdf.

11) Hojjati F, Adams RP, Terry RG. Discovery of chloroplast capture in Juniperus excelsa complex by multi- locus phylogeny. Phytotaxa. 2019;413(1):11-26. Available from: https://dx.doi.org/10.11646/phytotaxa.413.1.2.

12) Anwar M, Jasra AW, Sultani MI. Conservation and Sustainable Use of Biodiversity in Pakistan- A Review. Pakistan Agriculture. 2005;1(1):56-65.

13) Ahani H, Jalilvand H, Nasr SMH, Kouhbanani HS, Ghazi MR, Mohammadzadeh H. Reproduction of juniper (Juniperus polycarpos) in Khorasan Razavi, Iran. Forest Science and Practice. 2013;15(3):231-237. Available from: https://dx.doi.org/10.1007/s11632-013-0307-6.

14) Javanshir K. Research about seed production and method of growth in juniper trees in order to reclamation of juniper forests. 1981.

15) Amjad S. Coastal zones and marine fisheries. 1996.

16) Adams RP. Juniperus of Canada and the United States: Taxonomy, Key and Distribution. Lundellia. 2019;21(1):1-1.

17) Adams RP. Geographic variation in leaf essential oils and RAPDs of Juniperus polycarpos K. Koch in central Asia. Biochemical Systematics and Ecology. 2001;29(6):609-619. Available from: https://doi.org/10.1016/S0305-1978(00)00098-3.

18) Dierckxsens N, Mardulyn P, Smits G. NOVOPlasty:de novoassembly of organelle genomes from whole genome data. Nucleic Acids Research. 2016;45(4):e18. Available from: https://dx.doi.org/10.1093/nar/gkw955.

19) Hahn C, Bachmann L, Chevreux B. Reconstructing mitochondrial genomes directly from genomic next-generation sequencing reads-a baiting and iterative mapping approach. Nucleic Acids Research. 2013;41(13):e129. Available from: https://dx.doi.org/10.1093/nar/gkt371.

20) Hall TA. BioEdit: a user-friendly biological sequence alignment editor and analysis program for Windows 95/98/NT. Nucleic Acids Symp Ser. 1999. Available from: https://doi.org/citeulike-article-id:691774.

21) Saitou N, Nei M. The neighbor-joining method: a new method for reconstructing phylogenetic trees. Molecular Biology and Evolution. 1987;4(4):406-431. Available from: https://www.cabdirect.org/cabdirect/abstract/20013005316.

22) Kumar S, Stecher G, Tamura K. MEGA7: Molecular Evolutionary Genetics Analysis Version 7.0 for Bigger Datasets. Molecular Biology and Evolution. 2016;33(7):1870-1874. Available from: https://dx.doi.org/10.1093/molbev/msw054.

23) Kimura M. A simple method for estimating evolutionary rates of base substitutions through comparative studies of nucleotide sequences. Journal of Molecular Evolution. 1980;16(2):111-120. Available from: https://doi.org/10.1007/BF01731581.

24) Liu C, Shi L, Zhu Y, Chen H, Zhang J, Lin X, et al. CpGAVAS, an integrated web server for the annotation, visualization, analysis, and GenBank submission of completely sequenced chloroplast genome sequences. BMC Genomics. 2012;13(1):715. Available from: https://dx.doi.org/10.1186/1471-2164-13-715.

25) Kondo T, Tsumura Y, Kawahara T, Okamura M. Paternal Inheritance of Chloroplast and Mitochondrial DNA in Interspecific Hybrids of Chamaecyparis spp. Japanese Journal of Breeding. 1998;48(2):177-179. Available from: https://dx.doi.org/10.1270/jsbbs1951.48.177. 
26) Seido K, Maeda H, Shiraishi S. Determination of the selfing rate in a hinoki (Chamaecyparis obtusa) seed orchard by using a chloroplast PCR-SSCP marker. Silvae Genet. 2000;49(3):165-173. Available from: https://www.cabdirect.org/cabdirect/abstract/20013005316.

27) Chen J, Tauer C, Huang Y. Paternal chloroplast inheritance patterns in pine hybrids detected with trnL-trnF intergenic region polymorphism. Theoretical and Applied Genetics. 2002;104(8):1307-1311. Available from: https://dx.doi.org/10.1007/s00122-002-0893-5.

28) Hong YP, Krupkin AB, Strauss SH. Chloroplast DNA Transgresses Species Boundaries and Evolves at Variable Rates in the California Closed-Cone Pines (Pinus radiata, P. muricata, and P. attenuata). Molecular Phylogenetics and Evolution. 1993;2(4):322-329. Available from: https://dx.doi.org/10.1006/mpev. 1993.1031.

29) Dong J, Wagner DB. Paternally inherited chloroplast polymorphism in Pinus: estimation of diversity and population subdivision, and tests of disequilibrium with a maternally inherited mitochondrial polymorphism. Genetics. 1994;136(3):1187-1194. Available from: https://dx.doi.org/10.1093/ genetics/136.3.1187.

30) Wakasugi T, Hirose T, Horihata M, Tsudzuki T, Kossel H, Sugiura M. Creation of a novel protein-coding region at the RNA level in black pine chloroplasts: the pattern of RNA editing in the gymnosperm chloroplast is different from that in angiosperms. Proceedings of the National Academy of Sciences. 1996;93(16):8766-8770. Available from: https://dx.doi.org/10.1073/pnas.93.16.8766.

31) Eguiluz M, Rodrigues NF, Guzman F, Yuyama P, Margis R. The chloroplast genome sequence from Eugenia uniflora, a Myrtaceae from Neotropics. Plant Systematics and Evolution. 2017;303(9):1199-1212. Available from: https://dx.doi.org/10.1007/s00606-017-1431-x.

32) Zhou T, Chen C, Wei Y, Chang Y, Bai G, Li Z, et al. Comparative Transcriptome and Chloroplast Genome Analyses of Two Related Dipteronia Species. Frontiers in Plant Science. 2016;7(1512). Available from: https://dx.doi.org/10.3389/fpls.2016.01512.

33) Zhou T, Zhao J, Chen C, Meng X, Zhao G. Characterization of the complete chloroplast genome sequence of Primula veris (Ericales: Primulaceae). Conservation Genetics Resources. 2016;8(4):455-458. Available from: https://dx.doi.org/10.1007/s12686-016-0595-y.

34) Guo X, Liu J, Hao G, Zhang L, Mao K, Wang X, et al. Plastome phylogeny and early diversification of Brassicaceae. BMC Genomics. 2017;18(1):176-176. Available from: https://dx.doi.org/10.1186/s12864-017-3555-3.

35) Guo Q, Bianba D, Zheng W. Characterization of the complete chloroplast genome of Juniperus cedrus (Cupressaceae). Mitochondrial DNA Part A. 2016;27(6):4355-4356. Available from: https://dx.doi.org/10.3109/19401736.2015.1089498.

36) Li H, Guo Q, Zheng W. The complete chloroplast genome of Cupressus gigantea, an endemic conifer species to Qinghai-Tibetan Plateau. Mitochondrial DNA Part A. 2016;27(5):3743-3744. Available from: https://dx.doi.org/10.3109/19401736.2015.1079885.

37) Song X, Li J, Tso S, Xie S, Li L, Mao Q, et al. Characterization of the complete chloroplast genome of Juniperus recurva (Cupressaceae), the Dropping Juniper from the Himalaya. Mitochondrial DNA Part B. 2019;4(1):1219-1220. Available from: https://dx.doi.org/10.1080/23802359.2019.1591194.

38) Tso S, Li J, Xie S, Miao J, Hu Q, Mao K. Characterization of the complete chloroplast genome of Juniperus microsperma (Cupressaceae), a rare endemic from the Qinghai-Tibet Plateau. Conservation Genetics Resources. 2019;11(3):325-328. Available from: https://dx.doi.org/10.1007/s12686-018-1027-y.

39) Miao J, Tso S, Li J, Xie S, Mao K. The complete chloroplast genome of Juniperus tibetica (Cupressaceae), the conifer that occupies the highest known treeline in the Northern Hemisphere. Mitochondrial DNA Part B. 2019;4(1):609-611. Available from: https://dx.doi.org/10.1080/23802359.2018.1561229.

40) Palmer JD, Osorio B, Thompson WF. Evolutionary significance of inversions in legume chloroplast DNAs. Current Genetics. 1988;14(1):65-74. Available from: https://dx.doi.org/10.1007/bf00405856.

41) Wu CS, Wang YN, Hsu CY, Lin CP, Chaw SM. Loss of Different Inverted Repeat Copies from the Chloroplast Genomes of Pinaceae and Cupressophytes and Influence of Heterotachy on the Evaluation of Gymnosperm Phylogeny. Genome Biology and Evolution. 2011;3:1284-1295. Available from: https://dx.doi.org/10.1093/gbe/evr095.

42) Moore MJ, Soltis PS, Bell CD, Burleigh JG, Soltis DE. Phylogenetic analysis of 83 plastid genes further resolves the early diversification of eudicots. Proceedings of the National Academy of Sciences. 2010;107(10):4623-4628. Available from: https://dx.doi.org/10.1073/pnas.0907801107.

43) Olsson S, Grivet D, Cid-Vian J. Species-diagnostic markers in the genus Pinus: evaluation of the chloroplast regions matK and ycf1. Forest Systems. 2018;27(3):e016. Available from: https://dx.doi.org/10.5424/fs/2018273-13688.

44) Wu F, Li M, Liao B, Shi X, Xu Y. DNA Barcoding Analysis and Phylogenetic Relation of Mangroves in Guangdong Province, China. Forests. $2019 ; 10(1): 56$. Available from: https://dx.doi.org/10.3390/f10010056.

45) Snel B, Bork P, Huynen MA. Genome phylogeny based on gene content. Nature Genetics. 1999;21(1):108-110. Available from: https://dx.doi.org/10.1038/ 5052.

46) Nishiyama T, Wolf PG, Kugita M, Sinclair RB, Sugita M, Sugiura C, et al. Chloroplast Phylogeny Indicates that Bryophytes Are Monophyletic. Molecular Biology and Evolution. 2004;21(10):1813-1819. Available from: https://dx.doi.org/10.1093/molbev/msh203.

47) Zhang ZL, Ma LY, Yao H, Yang X, Luo JH, Gong X. The complete chloroplast genome of Cupressus chengiana. Conservation genetics resources. 2017;9:347356. Available from: https://doi.org/10.1007/s12686-016-0675-z. 